\title{
Hyperglycemia in PICU- Predictor of outcome
}

\author{
Rabindran', Gedam DS ${ }^{2}$ \\ ${ }^{1}$ Dr. Rabindran, Consultant Neonatologist, Billroth Hospital, Chennai, ${ }^{2}$ Dr D Sharad Gedam, Professor of Pediatrics, L N \\ Medical College, Bhopal, MP, India.
}

Address for Correspondence: Dr Rabindran, E mail: rabindranindia@yahoo.co.in

\begin{abstract}
Stress hyperglycemia is common in pediatric critical illness. It is associated with poor outcome in large number of patients.
\end{abstract}

Keywords: Hyperglycemia, Pediatric ICU stay, Mortality

\section{Introduction}

Hyperglycemia is a stress response of disturbed homeostasis in critically ill patients due to peripheral insulin resistance, relative insulin deficiency, impaired glucose metabolism and effect of medications like catecholamine, glucocorticoids and exogenous dextrose administration [1]. Mechanical ventilation, vasoactive infusions, renal replacement therapies, cardiopulmonary bypass and extracorporeal life support, therapeutic hypothermia, prolonged immobility, nutrition support practices also contribute to hyperglycemia in Paediatric Intensive Care Units (PICU). Stress hyperglycemia is common in pediatric critical illness, with about $49-72 \%$ children having glucose concentrations more than 150 $\mathrm{mg} / \mathrm{dl}$ (>8.3 mmol/liter)[2].

Hyperglycemia is associated with mortality, multiple organ dysfunction\& morbidities like prolonged requirement of ventilation, inotropic support \& prolonged length of PICU stay [3]. Hyperglycemia stimulates a cascade of proinflammatory events, is prothrombotic, increases oxidative stress by lipid peroxidation, causes endothelial dysfunction, promotes infection by decreasing neutrophil phagocytic activity and oxidative burst of leukocytes [4]. It exacerbates ischemic brain injury, myocardial cell apoptosis due to reactive oxygen species \& affects pulmonary and renal tissue due to free radical injury [5]. Hyperglycemia causes cellular toxicity \& apoptosis by causing intracellular glucose overload \& oxidative phosphorylation [6].

Hyperglycemia prolongs duration of mechanical ventilation directly via lung damage and indirectly through development of critical illness myopathy [7]. It promotes osmotic diuresis with hypovolemiaand electrolyte abnormalities like hypokalemia, hypomagnesemia, hypophosphatemia and also worsens catabolism in skeletal muscle. It impairs fibrinolysis and platelet function leading to hypercoagulability [6]. It causes abnormalities in vascular reactivity and endothelial dysfunction leading to compromised microcirculation and subsequent cellular hypoxia leads to organ failure and death in critically ill patients.

Studies have shown that peak glucose levels and longer duration of hyperglycemia significantly correlated with predicted mortality and negatively correlated with ventilator free days at 30 days [8]. Peak glucose concentrations tend to be much higherin nonsurvivors compared with survivors [9]. Similarly, nonsurvivors tend to have exposure to longer duration of Hyperglycemia compared with survivors [10]. This association of Stress Hyperglycemia with mortality appears across different pediatric diseasestates, including septic shock, burns, traumatic brain injury, post cardiac surgery and trauma. Hyperglycemia is associated with longer periods of intensive care unit stayand more frequent nosocomial infections [9].

Patients with blood glucose more than $10 \mathrm{mmol} / \mathrm{L}$ have worse outcome. Arecent NICE-SUGAR study demonstrated that moderate glucose control (140-180 $\mathrm{mg} / \mathrm{dl}$ ) wass associated with lower mortality [11]. Tight glucose control to manage Stress Hyperglycemia is emerging as a promising therapy to improve outcomes in critically ill children. Hence hyperglycemia can be 
useful as a predictor of outcome in pediatric intensive care units \& prompt management of glycemic state can improve outcome and reduce morbidity and hospital stay among critically ill children.

Jain $h$ et al has in this issue published an article in this issue \& noted that intense hyperglycemia during first 24 hours of PICU admission was associated with higher mortality rate and a longer duration of PICU stay in their study [12].

\section{Reference}

1. Annane D, Melchior JC. Hormone replacement therapy for the critically ill. Crit Care Med. 2003 Feb;31(2):634-5.

2. Gupta P, Natarajan G, Agarwal KN. Transient hyperglycemia in acute childhood illnesses: to attend or ignore? Indian J Pediatr. 1997 Mar-Apr;64(2):205-10.

3. Bhutia TD, Lodha R, Kabra SK. Abnormalities in glucose homeostasis in critically ill children. PediatrCrit Care Med. 2013 Jan;14(1):e16-25. doi: 10.1097/ PCC. 0b013e3182604998.

4. Corstjens AM, Van der Horst ICC, Zijlstra JG, Johan Groeneveld AB, Zijlstra F, Tulleken JE, et al. Hyperglycemia in critically ill patients: marker or mediator of mortality? Crit Care. 2006; 10(3): 216. doi: 10.1186/cc4957.

5. Srinivasan V, Spinella PC, Drott HR, Roth CL, Helfaer MA, Nadkarni V. Association of timing, duration and intensity of hyperglycemia with intensive care unit mortality in critically ill children. PediatrCrit Care Med. 2004 Jul;5(4):329-36.

6. Van den Berghe G. How does blood glucose control with insulin save lives in intensive care? J Clin Invest. 2004 Nov 1; 114(9): 1187-1195.doi: 10. 1172/ JCI200423506.
7. Stevens RD, Dowdy DW, Michaels RK, MendezTellez PA, Pronovost PJ, Needham DM. Neuromuscular dysfunction acquired in critical illness: a systematic review. Intensive Care Med. 2007 Nov; 33(11):1876-91. Epub 2007 Jul 17.

8. Day KM, Haub N, Betts H, Inwald DP. Hyper glycemia is associated with morbidity in critically ill children with meningococcal sepsis. PediatrCrit Care Med. 2008 Nov;9(6):636-40. doi: 10.1097/PCC. 0b013e31818d350b.

9. Hirshberg E, Larsen G, Van Duker H. Alterations in glucose homeostasis in the pediatric intensive care unit: Hyperglycemia and glucose variability are associated with increased mortality and morbidity. PediatrCrit Care Med. 2008 Jul;9(4):361-6. doi: 10.1097/PCC. 0b013e318172d401.

10. Ulate KP, Lima Falcao GC, Bielefeld MR, Morales JM, Rotta AT. Strict glycemic targets need not be so strict: a more permissive glycemic range for critically ill children. Pediatrics. 2008 Oct;122(4):e898-904. doi: 10. 1542/peds. 2008-0871. Epub 2008 Sep 8.

11. NICE-SUGAR Study Investigators, Finfer S, Chittock DR, Su SY, Blair D, Foster D, Dhingra V, Bellomo R, Cook D, Dodek P, Henderson WR, Hébert PC, Heritier S, Heyland DK, McArthur C, McDonald E, Mitchell I, Myburgh JA, Norton R, Potter J, Robinson $\mathrm{BG}$, Ronco JJ. Intensive versus conventional glucose control in critically ill patients. N Engl J Med. 2009 Mar 26;360(13):1283-97. doi: 10.1056/ NEJ Moa0810625. Epub 2009 Mar 24.

12. Jain H, Arya S, Mandloi R.The prevalence of hyperglycemia in critically ill children admitted in PICU. Int J Pediatr Res.2016;3(6):467-471.doi:10. 17511/ijpr.2016.6.16.

\section{How to cite this article?}

Rabindran, Gedam DS. Hyperglycemia in PICU- Predictor of outcome. Int J Pediatr Res.2016;3(6):378379.doi:10.17511/ijpr.2016.i06.01. 